Faculty of Law

Faculty Publications

The Surprise of Invention: Making Fun of the Statutory

Cressida Limon \& Sara Ramshaw

2012

"This is an Accepted Manuscript of an article published by Taylor \& Francis in Australian Feminist Law Journal on 03 Jul 2014, available online:

https://www.tandfonline.com/doi/abs/10.1080/13200968.2012.10854473

Citation for this paper: Cressida Limon \& Sara Ramshaw (2012) The Surprise of Invention: Making Fun of the Statutory, Australian Feminist Law Journal, 37:1, 3-13 


\title{
THE SURPRISE OF INVENTION: MAKING FUN OF THE STATUTORY
}

\section{Cressida Limon* \\ Sara Ramshaw**}

For this special issue of The Australian Feminist Law Journal we asked contributors to critically address questions about law in its relation to, and as, technology through the thematic of invention. Invention, as the late French philosopher Jacques Derrida argued, is both necessary and impossible. Law is inventive or it is nothing at all! At least, that's what we said then. This slogan, which echoes Derrida: 'Deconstruction is inventive or it is nothing at all'1 requires further elaboration. Now, in this introduction we consider three aspects of invention that we have found (invented and/or discovered) in the papers collected here: Plasticity, Creativity and Justice. Although Derrida linked deconstruction and invention (and as we shall see, law and technology) he also wrote that deconstruction

\begin{abstract}
does not settle for methodical procedures, it opens up a passageway, it marches ahead and marks a trail; its writing is not only performative, it produces rules — other conventions — for new performativities and never installs itself in the theoretical assurance of a simple opposition between performative and constative. $^{2}$
\end{abstract}

For Derrida, invention is intricately connected to singularity and alterity through technology. With modernity, he writes in 'Psyche: Inventions of the Other,' came a 'new regime of invention.'3 Originally, two competing meanings coexisted. Firstly, there was the notion of invention as discovery, of 'invention of what was already there and came into view as an existence or as meaning and truth.' This meaning was overtaken in the seventeenth century by 'the productive invention of a technical apparatus that was not already there as such, ${ }^{5}$ that is, as Landgraf explains, the understanding of invention as 'a mode of producing the singular and new.' ${ }^{\prime}$ The modern

\footnotetext{
* Cressida Limon is a Research Fellow at the Melbourne Law School, The University of Melbourne. Email: cressida.limon@unimelb.edu.au. Cressida and Sara thank the General Editor, Judith Grbich, for all her support and advice and the Editorial Board of the AFLJ. We would also like to thank the anonymous reviewer for their comments on the paper.

** Sara Ramshaw is a Lecturer at Queen's University Belfast School of Law. Email s.ramshaw@qub.ac.uk.

1 Derrida Jacques 'Psyche: Invention of the Other' Porter Catherine (trans) in Kamuf Peggy and Rottenberg Elizabeth (eds) Psyche: Inventions of the Other Volume 1 Stanford University Press Stanford 2007 p 1 at 23.

2 As above at 23.

As above at 37.

4 As above at 31 .

As above.

6 Landgraf Edgar Improvisation as Art: Conceptual Challenges, Historical Perspectives Continuum New York and London $2011 \mathrm{p}$ 27.
} 
understanding, linked to technology, conceives invention extemporaneously ${ }^{7}$ as that which offers 'a place upon finding it.' ${ }^{\text {' }}$ Prior to this reinvention of invention, 'its place was found there where it was already located.'

Invention, in this modern, technologically-minded sense, is impossible without law. According to Derrida, invention, must, by definition, 'overflow, overlook, transgress, negate'10 that from which it comes. It exists, in other words, solely on the condition that it transgresses the 'status' with which it is supposed to comply. ${ }^{11}$ This status acts as law and is constituted as 'stable, established, and legitimated by a social or symbolic order in an institutionalizable code, discourse, or text.' 12 That is why, for Derrida, 'every invention should make fun of the statutory;"13 it always presupposes some illegality, or 'the breaking of an implicit contract.'14 Invention without law, or what Derrida calls the 'invention of the other,'15 is an impossibility because there can be no invention 'without a prevailing statutory context.'16

The singular event of invention thereby demands simultaneous capture within a system of conventions that will ensure its position more generally in culture and society. ${ }^{17}$ Whilst the event of invention 'can take place only once,' 18 invention more generally must be 'essentially repeatable, transmissible, and transposable.'19 'To invent,' writes Derrida, 'is to produce iterability,' that is, repetition of the originary inventive event. It is therefore a paradox or aporia that invention is founded solely on singularity and uniqueness and yet can only be recognized as inventive by compromising its singularity in 'repetition' and 'generality.'20 Wholly dependent on generality for recognition and legitimation, invention remains forever lodged within the 'order of the calculable,' the 'order of the same, ${ }^{21}$ which is, for Derrida, the order of law. ${ }^{22}$ To be otherwise would make its recognition as invention impossible. Invention thus needs to be with law to be

'Extempore' literally means 'out of the time': The Oxford English Reference Dictionary 2nd ed Pearsall Judy and Trumble Bill (eds) Oxford University Press Oxford 1996 p 494. The extempore as 'performative immediacy' is deconstructed by Derrida in relation to law and justice in 'Declarations of Independence' (1986) 15 New Political Science 7 and 'The Laws of Reflection: Nelson Mandela, In Admiration' Caws MA and I Lorenz I (trans) in Derrida Jacques and Tlili Mustafa (eds) For Nelson Mandela Seaver Books New York 1987 p 13.

8 Derrida above note 1 at 31, emphasis in original.

9 As above, emphasis in original.

10 As above at 21.

11 As above at 21

12 As above at 26

13 Derrida Jacques 'Psyche: Inventions of the Other' Porter Catherine (trans) in Waters Lindsay and Godzich Wlad (eds) Reading de Man Reading University of Minnesota Press Minnesota 1989 p 25 at 45. In the revised translation this passage has been rendered: 'no invention should care in the least about the statutory': Derrida above note 1 at 26.

14 As above at 1.

15 As above at 39

16 As above at 26

17 As above at 6.

18 As above at 34.

19 As above at 34.

20 As above at 34 .

$21 \quad$ As above at 39.

22 Derrida Jacques 'The Law of Genre' in Acts of Literature Attridge Derek (ed) Routledge New York and London $2002 \mathrm{p}$ 244. 
inventive. Its originality can only be 'display[ed], ${ }^{23}$ can only be brought into presence or made present, through law, through the 'values of form and composition. ${ }^{24}$ Law is therefore necessary not only for invention to be 'recognized, identified, legitimized' as invention, but also for it 'even to occur, or, let us say, for it to come about.'25

\subsection{INVENTION AND Plasticity}

To invent and most particularly understanding invention as an event, means here to rediscover what was there without being there, both in language and in philosophy; it is a question of finding, yes, but of finding for the first time what was always there and what had always been there, to find again, almost to re-find, something in its (contradictory) fusion and in its (atomic) fission where it had never before been seen, to invent it almost, as one would invent a bomb, but to discover it also almost like the excessively obvious evidence of a purloined letter: never seen, never known, never waited on or for, never expected as such, while all the while only expecting it and not expecting anything else but it, the unexpected. ${ }^{26}$

A bomb and a letter are exemplary inventions according to Derrida and the exemplar is a concept close to that of invention. It is not simply a matter that war (and militarism in general) and technology have always been related in the sense of the empirical proliferation of inventions (machines) in times of warfare (when isn't it?). ${ }^{27}$ Derrida hypothesises that 'since the end of the seventeenth century in Europe, there are only two major types of authorized inventions. 28

On the one hand, people invent stories (fictional or fabulous), and on the other hand they invent machines, technical devices or mechanisms, in the broadest sense of the word. Someone may invent by fabulation, by producing narratives to which there is no corresponding reality outside of the narrative (an alibi, for example), or else one may invent by producing a new operational possibility (such as printing or nuclear weaponry, and I am purposely associating these two examples, since the politics of invention is always at one and the same time a politics of culture and a politics of war). ${ }^{29}$

Catherine Malabou, in her recent book, also addresses the theme of invention and rediscovery when she re-cites Derrida's reference to the bomb and the purloined letter. ${ }^{30}$ This recitation is part of an exchange between Malabou and Derrida. Malabou is trying to invent plasticity and Derrida is not convinced she can. For Derrida 'plasticity is always dialectical. 31

23 Derrida above note 1 at 3.

As above.

As above at 25 , emphasis in original.

26 Derrida Jacques 'A Time for Farewells: Heidegger (read by) Hegel (read by) Malabou' Preface to Malabou Catherine The Future of Hegel, Plasticity, Temporality and Dialetic Routledge London $2005 \mathrm{p}$ i at xvi.

27 See Haraway on industrial militarism in particular: Haraway Donna J Simians, Cyborgs, and Women: The Reinvention of Nature Routledge New York 1991.

28 Derrida as above note 1 at 10 , emphasis in original

29 Derrida as above, emphasis in original.

30 Malabou Catherine Changing Difference: The Feminine and the Question of Philosophy Shread Carolyn (trans) Polity Cambridge 2011 at 68-69.

31 As above at 79. This is Malabou's comment. 
Plasticity, as Malabou notes 'refers to a dual ability to receive form (clay is plastic) and give form (as in the plastic arts or plastic surgery). ${ }^{32}$ Malabou is seeking to re-invent Plasticity through her reading of Hegel, and the philosophical and political stakes of 'recognition.' Feminism and sexual difference are central to Malabou's philosophical practice. Malabou's account of plasticity is an apt one for this Special Issue. The phoenix, the spider and the salamander, are, in Malabou's work, the figures for writing about philosophical invention. The phoenix, the mythical bird that rises from its own ashes to live again, is an image of the new from the same. This is a kind of auto-invention, or, in Malabou's reading of Hegel, a process that gathers everything up into itself and 'leaves no scars behind." 33 The spider, and its webs and weaving are like writing, 'the constant return of the web, the repair, the lucky chance. ${ }^{34}$ The spider spins a web but unlike the phoenix the activity of the spider 'far from permitting the return of an intact, undamaged presence, this type of erasure marks precisely the originary impossiblity of presence. ${ }^{35}$ This is invention as deconstruction (even if that is impossible). The salamander is Malabou's figure for a form of invention that is a regeneration. ${ }^{36}$ This is not the same as the phoenix. The salamander's ability to regenerate a limb is not the phoenix's resurrection, nor the spider's reiterations. ${ }^{37}$ The salamander is a figure for invention as plasticity. 'Regeneration is therefore not a reconstitution of presence, but rather a regeneration of difference. Here "to recover" ... implies a finite survival, a momentary resource. ${ }^{3} 3$

When Derrida writes of invention as an event he is writing about invention as a singularity. Invention, like justice, friendship, the gift, is in Derrida's philosophy 'undeconstructable. ${ }^{39}$ What does it mean to say that invention (or justice, or friendship) is undeconstructable? And why might this be interesting for feminists and others? Malabou provides one possible response when she writes about how, as a feminist philosopher, she encountered a problem with Derridean deconstruction. This problem was not just that deconstruction itself (whatever that might mean) became programmable — that is, open to a set of procedures or a formula, and therefore became unjust. It was also an ethical problem. The papers in this collection address ethical problems, as questions of law and invention.

Karen O'Connell's article 'A Plural Thing: Inventing a Feminist Brain-Based Subject of Law' addresses the relationship between neuro-techno-sciences and legal accounts of subjectivity. O'Connell's concern is to highlight the potential of the moment when 'new' technoscientific accounts are perhaps most open or destabilising of the status quo. At the same time, there is always the danger of recuperation within dominant medico-legal discourses. Thus, in the

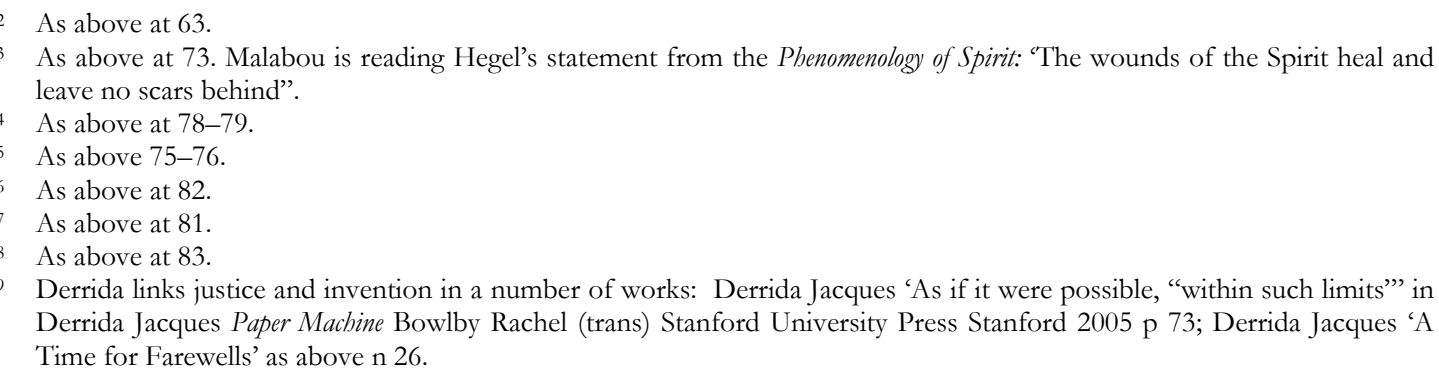


'mainstream' or popular accounts of 'the brain' there is already a clear paradox in the reductive accounts of biology (or neurology) and at the same time a repressive account of individual 'responsibility' to submit to medical intervention (ie. pharmacology). A particularly striking example cited by O'Connell was the suggestion that 'a good knowledge of the brain's system of justice and of how the brain reacts to conflicts may provide critical tools in resolving international political and economic conflicts. ${ }^{40}$ As O'Connell points out such an account pictures the 'brain' in total isolation and as somehow a legal agent of its own account.

Having set out the complex set of relations that suggest the likely forms of complicity between neuroscience and law in terms of notions of objectivity, boundedness, rationality, asociality, individuality etc. O'Connell resituates the problem within feminist debates about 'equality.' O'Connell contrasts the strategies of trying to 'stretch' existing legal categories, to the feminist practices of inventing new legal concepts. In her words, invention 'claims a space as nolonger-unknown. This opens up the possibility of demarcating a legal space for formerly unspoken experiences.'41 Thus invention, both uncovering what was already found there, but instituting a form that is repeatable. In this sense, feminists have always engaged in inventive political, legal and social forms. That these inventions have been successful may be suggested by the response that still would find these inventions 'dangerous.' At the same time, the necessity to constantly re-invent is also emphasised. Martha Fineman's vulnerability thesis is approached in this context. However, O'Connell identifies the need for conceptualizing the 'brain-based' subject otherwise, as one located in social relationships and more radically, understanding of the brain, as the 'place where we become other people.'42

Technologies, of course, do not stay put, rather they are mobile and produce a range of aesthetic, normative, and other processes. Giorgio Agamben, in his reflections on the notion of an 'apparatus,' as it developed in Foucault's work, writes about the shift from the production of subjectivities to forms of 'desubjectification.' 43 Agamben argues in his essay that an 'apparatus':

Designates that in which, and through which, one realizes a pure activity of governance devoid of any foundation in being. This is the reason why apparatuses must always imply a process of subjectification, that is to say, they must produce their subject. ${ }^{44}$

Agamben distinguishes modern apparatuses from those considered by Foucault that produce subjects in a disciplinary society. The problem, as Agamben sees it, is that now apparatuses act more in terms of 'desubjectification. ${ }^{\prime 45}$ Desubjectification no longer suggests a re-subjectification

40 Zeki Samir and Goodenough Oliver 'Law and the Brain: An Introduction' in Zeki Samir and Goodenough Oliver (eds) Law and the Brain Oxford University Press Oxford $2004 \mathrm{p}$ i at xiv cited in O'Connell Karen 'A Plural Thing: Inventing a Feminist Brain-Based Subject of Law' 37 Australian Feminist Law Journal (this volume).

41 As above (O’Connell).

42 As above.

43 Agamben Giorgio 'What is an Apparatus?' in What is an Apparatus? And Other Essays Kishik David and Pedatella Stefan (trans) Stanford University Press Stanford 2009 p 1.

44 As above at 11.

45 As above at 20. 
(a new truth of the subject). Instead there is an indifference. ${ }^{46}$ It is arguable that this indifference is characteristic of international human rights law.

Tom Dreyfus' article 'The "Half-Invention" of Gender Identity in International Human Rights Law: From CEDAW to the Yogyarkata Principles' examines the discursive production of the subjects of human rights law. Dreyfus addresses a form of legal invention - in the international human rights machine. The aspirations of Human Rights are argued to lack the necessary inventiveness that would truly bring about a radical change in the lives of marginalized subjects. As Dreyfus succinctly puts it 'Operating within the language and framework of the international human rights discourse, the Principles cannot (and must not) surprise or unsettle too much. ${ }^{47}$ In this respect Dreyfus contrasts calls for an invention that goes beyond the tired models of identity and recognition. The politics of recognition, and its basic assumptions of a proper self - the one who would recognise or be the basis for the other's recognition, recalls the figure of the phoenix and plasticity. ${ }^{48}$ It is clear that CEDAW's limitation's are problematic — but what other sort of fluid universalisms are capable of inventing anew humanity or humanity anew? Could human rights law surprise us yet?

\subsection{INVENTION AND CREATIVITY}

Invention, as mentioned above, is both necessary and impossible for Derrida. This impossible invention of the other, or what Derek Attridge calls the 'creation of the other,'49 links law, invention and technology to creativity. Attridge explains: "To be truly creative is to wrest from the realm of the familiar the hitherto unthought, to bring into existence by skilful and imaginative intellectual labor an entity that is irreducibly different to what is already in being. ${ }^{50}$ Yet, this creative inventiveness also has 'an element of passivity, of attempting to heighten responsiveness to hints of relationships, to incipient arguments, to images swimming on the edges of consciousness, an element of "letting them come" as much as seeking them out." 51 The new and original, in other words, is never simply produced by the 'active shaping of existing, conscious, mental materials'; ${ }^{52}$ there is always an element of mystery to the process and product. ${ }^{53}$ Thus, for

46 As above at 21.

47 Dreyfus Tom 'The Half-Invention' of Gender Identity in International Human Rights Law: From CEDAW to the Yogyakarta Principles' (2012) 37 Feminist Law Journal (this volume).

48 Bhandar Brenna 'Plasticity and Post-Colonial Recognition: "Owning, Knowing and Being'”" (2011) 22 Law and Critique 227.

49 Attridge Derek The Singularity of Literature Routledge London and New York 2004 p 22.

50 As above.

51 As above at 22-3.

52 As above at 23

53 As Attridge points out, this 'familiar point' has been 'clearly articulated by Kant in his discussion of genius':

If an author owes a product to his genius, he himself does not know how he came by the ideas for it; nor is it in his power to devise such products at his pleasure, or by following a plan.

Kant, cited in Attridge above note 38 p 150 fn 9. 
Attridge, 'the creation of the other' simultaneously refers to the act of creating and that which is created by the other. ${ }^{54}$ Attridge explains:

\begin{abstract}
... the act of breaking down the familiar is also the act of welcoming the other; the event of the familiar breaking down is also the event of the irruption of the other. ... If one is able to break down the old in a creative and not just a negative manner (and at the time it is not possible to be sure which of these one is doing), the new comes into being; at the same time, the breakdown of the old is produced by the pressure of its internal contradictions - which, since its contradictions are a function of what it excludes, is the same as saying that it breaks down under the pressure of the other. ${ }^{55}$
\end{abstract}

Accordingly, invention as creativity signifies here the notion that 'novelty is achieved by means both of the refashioning of the old and of the unanticipated advent of the new; or, more accurately if more paradoxically, that the advent of the new is a particular kind of refashioning of the old. ${ }^{56}$ In the words of Attridge: 'Thinking creatively about creation means thinking of these as two sides of the same coin. ${ }^{57}$

Many of the papers in this special issue bring to the fore the creative dimensions of law, invention and technology as they relate to issues of utmost importance to feminists and critical legal scholars alike. In 'Myths of Invention: Law, and the Ignorance about Genetics, ${ }^{58}$ Cressida Limon creatively fashions her feminist account of invention on the philosophy of Adriana Cavarero, specifically Cavarero's interrogation of the ancient myth of Demeter as an example of classical (masculine) philosophy's 'ignorance about genetics.' The novelty and inventiveness of Limon's argument emerges from her refashioning of the old (mythical) to say something original about the modern law of (biological) invention (of which intellectual property rights are exemplary). Despite the attempt by JBS Haldane in 1923 to banish mythology from modern science, Limon demonstrates how this alleged expulsion did not rid science of the mythical, but simply created a new mythology based on a biological invention free of myth. ${ }^{59}$ Limon shows how myth continues to inform both the modern science of biological invention and the modern law of intellectual property, particularly the myth of parthenogenesis, or the idea that reproduction can be divorced from genetics. In the final section of her paper, Limon stresses that this approach to biological invention, both in science and in law, is a question of sexual difference. She reads Clarice Lispector's final novel, A Breath of Life, as an invention of a different genealogy of invention in which law plays a key role. Ultimately, for Limon, the question of invention is one of law, a question whose answer is not dependent on empirical or chronological data, but one that breathes life into the current mythology of modern invention as that which is free of myth.

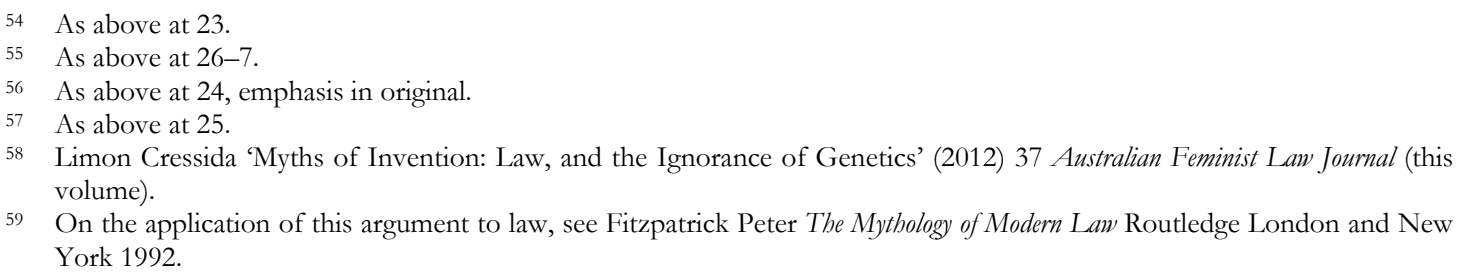

59 On the application of this argument to law, see Fitzpatrick Peter The Mythology of Modern Law Routledge London and New York 1992. 
This exploration of the mythological dimensions of modern law and invention continues in Chris Lloyd's paper, 'ce qui arrive': Deconstruction, Invention and the Legal Subject of $R . v R^{\prime 60}$. Applying the philosophy of Jacques Derrida to the revolutionary English criminal law case R. $v$ R [1992] 1 AC 599, Lloyd questions the radical potential of this case as in instance of 'true' invention in law. 'True' invention, or what Derrida calls 'invention of the other,' ${ }^{\prime 1}$ is, as mentioned above, a necessary impossibility. It is impossible in the sense that there can be no invention 'without a prevailing statutory context.' ${ }^{2}$ By maintaining the notion of a 'true alterity,'63 though, Derrida is able to account for singularity and originality ('true' invention) without risking entrapment in some pre-existing order in which invention is absorbed or negated.64 The impossibility of invention thus becomes a condition of its possibility.

The creative power of invention is frequently said to lie in its originality. And yet what Lloyd demonstrates is that invention 'happens' not simply as an 'unfolding of potential that arises anew out of shifting contexts that compose the here and now.' ${ }^{25}$ The unique event of creative expression must paradoxically repeat itself in its uniqueness. ${ }^{66}$ Invention, in other words, must itself be iterable, repeatable. Otherwise, we could not know it as creative and original and thereby inventive. Invention would accordingly be incomplete without repetition, just as repetition is impossible without invention. In his paper, Lloyd looks to the invention of marital immunity from rape in law to interrogate the radical and emancipatory potential inherent in the necessary iterability of a legal happening. Focusing on the origins of Sir Matthew Hale's legal pronouncement, Lloyd draws attention to the conceptual grounding of law in fiction and mythology, ${ }^{67}$ which 'allows for a malleability disguised as fixity.' ${ }^{68}$ This malleability, as a defence against stasis, allows for the repetition or re-invention of invention and is necessary for 'true' invention to 'happen.'

Eugene Mc Namee’s paper, 'An Egg Shaped Bowl: Law, Invention, Technology,'69 similar in focus to that of Limon's, looks to the legal regulation of new genetic technologies to situate law as itself a form of technology, one that, relying on the insight of Heideggerean theory read through Foucault, (re-) invents legal subjectivity as a technology of the self. Mc Namee complicates this picture of law (and the subject of law as a question of the distinction between 'persons' and 'things') through the legal anthropological writings of Alain Pottage, illustrating that 'life is and always has been conjured as much as revealed, and law has always been part of this

60 Lloyd Chris 'ce qui arrive': Deconstruction, Invention and the Legal Subject of R. $v$ R' (2012) 37 Australia Feminist Law Journal (this volume).

61 Derrida above note 1 at 39

62 As above at 26.

63 Landgraf above note 4 at 31.

64 As above at 29.

65 Fischlin Daniel “Wild notes” ... Improvisioning' (2010) 6(2) Critical Studies in Improvisation. Available HTTP: www.criticalimprov.com/article/view/1358/1937 (accessed 24 November 2012) at 6.

66 As above.

67 For this point, Lloyd relies on the work of Peter Fitzpatrick, specifically, Modernism and the Grounds of Law Cambridge University Press Cambridge 2001.

68 Lloyd above note 59.

69 Mc Namee Eugene 'An Egg Shaped Bowl: Law, Invention, Technology' (2012) 37 Australian Feminist Law Journal (this volume). 
process. ${ }^{70}$ Life, law, technology and invention is further theorised through the work of Lewis Mumford, whose anthropologic studies of pre-history bridge the 'study of human nature and technology as the pattern of human interventions into nature. ${ }^{71}$ Early man's first task was to gain control over himself and this was done through the limited technique of ritualisation. Here, Mc Namee conceives invention as a singularity or originality that is only made possible in repetition and ritual. Going further, though, Mc Namee himself invents a new approach to law, invention and technology by demonstrating how this capacity to repeat, according to Mumford, flowed from the body and the physicality of men and women. This location of invention in the body calls for an analysis of technology based on sexual difference, one that Heidegger ignores, but Luce Irigaray provides in Mc Namee's paper.

\subsection{THE JUSTICE OF INVENTION}

Staying on the theme of sexual difference, we find that invention, be it biological or otherwise, cannot but operate within the phallogocentric, and thus patriarchal, structures of law and society. As such, any discussion of law, invention and technology (including those in this special issue) cannot simply renounce its complicity with phallogocentrism 'without also giving up the critique we are directing against this complicity. ${ }^{72}$ Complicity, in other words, brings us into a relation, or creates a violent "partnership' 73 with phallogocentrism, which thereby enables us to challenge such. Whereas phallogocentrism tries to deny the violence of the opposition between Self and Other ${ }^{74}$ and "nourishes the desire for a "truth" that would be free of violence, deconstruction teaches us to own up to our complicity in the suffering we cannot help but produce ${ }^{75}$ and to understand that there is no such thing as non-violence in a phallogocentric system; our only ethical choice is that of 'the lesser violence within an economy of violence."76

Invention (along with any re-invention of invention) is accordingly constrained by its violent complicity with phallogocentrism. And it is the necessity of this complicity, which oft leads to charges of 'destruction and negativity'77 being laid against Derrida and deconstruction. The falsity and unfairness of these charges, however, is made acutely obvious upon a closer

70 As above.

71 As above.

72 Derrida Jacques 'Structure, Sign, and Play in the Discourse of the Human Science' Bass Alan (trans) in Derrida Jacques Writing and Difference Routledge London and New York 1978 p 351 at 355.

73 'Complicity' is defined in the Oxford English Reference Dictionary (OERD) as 'partnership in a crime or wrongdoing': OERD 2nd ed Pearsall Judy and Trumble Bill (eds) Oxford University Press Oxford 1996 p 296.

74 Chung-Hsiung Lai 'On Violence, Justice and Deconstruction' (2003) 29(1) Concentric: Studies in English Literature and Linguistics $\mathrm{p} 23$.

75 Fleming Marie 'Review of Derrida and the Political; Feminist Interpretations of Jacques Derrida' (1998) 31(2) Canadian Journal of Political Science 420 at 420.

76 Derrida Jacques 'Violence and Metaphysics: An Essay on the Thought of Emmanuel Levinas' Bass Alan (trans) in Derrida Jacques Writing and Difference Routledge London and New York 1978 p 97 at 400, fn 21, emphasis in original.

77 Shildrik Margrit Embodying the Monster: Encounters with the Vulnerable Self SAGE Publications London Thousand Oaks New Delhi 2002 p 129. 
examination of the creativity of deconstructive thought. Invention involves both a 'situatedness and datedness, ${ }^{78}$ but also difference and surprise. It thereby 'possesses the paradoxical quality of a singularity that is confirmed only in repetitions, and in repetitions that are different every time. ${ }^{79}$ It is the necessary iterability of the event of creativity, which gives iterability its creativity and permits the invention of the unique and surprising.

It is this singular, creative (and surprising) invention, which brings us into the realm of justice and the ethical. Attridge argues that ' $[t]$ he other, the unprecedented, hitherto unimaginable disposition of cultural materials that comes into being in the event of invention, is always singular.' ${ }^{80}$ This relation to singularity and otherness 'arouses ... a sense of responsibility,' involving both a responsibility to the other — 'the other calls me to account, I answer to it as best I can' and a responsibility for the other: 'Being responsible for the other involves assuming the other's needs (if only the need to exist), affirming it, sustaining it, being prepared to give up my own wants and satisfactions for the sake of the other. ${ }^{\prime 81}$ Responsibility 'is an ethical term,' one that 'implies an "ought." 82 Being responsible for the other, 'as it comes into being (and thus bring it into being),' asserts Attridge, 'is to be under an obligation to it.' ${ }^{83}$ It is this 'ethical responsibility for the other,' which lies 'at the heart of creativity. ${ }^{\text {'84 }}$

To conclude, any critical reading of law, invention and technology, which is concerned with the issue of gender, must, to quote Elisabeth Grosz, be 'committed to both an affirmation, a saying-yes to patriarchy (the gesture of phallogocentrism), and an affirmation of feminism, an affirmation of the overcoming of patriarchy.' ${ }^{85}$ Although many feminists would prefer to 'simply and resoundingly say no to patriarchy,' the 'inherited nature of feminist discourse' means that we are constitutively immersed 'in the very systems from which we seek to distance, and against which we seek to position, ourselves.' ${ }^{86}$ Thus, critical theorisations, such as the ones offered in this special issue, alert feminists and other critical scholars to 'the danger of repeating and being unable to recognize the very implications it believes it has repudiated. ${ }^{87}$ Critical theory is necessary then to challenge our 'complicity with the very forces feminists have commonly identified as outside of, and other to, as different from feminism itself.' 88 For it is only by acknowledging this complicity that we can direct our critique against it. ${ }^{89}$ 'The task,' then, to quote Shildrick once again, 'is not to destroy the foundations of the logos so much as to open them up

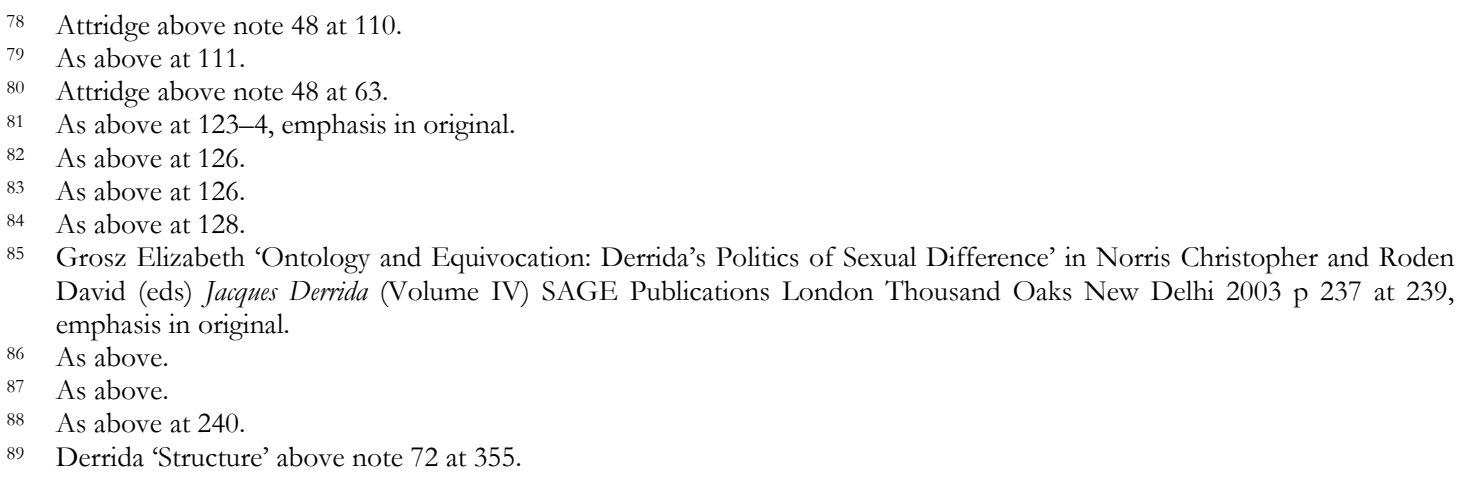


to take account of all that has hitherto been excluded or disavowed. ${ }^{90}$ The task, in other words, is to help prepare us to welcome the impossible invention, which is an invention that never arrives, but which promises nevertheless 'gradual and necessary transformation' ${ }^{11}$ within Western law and society. At once an impossibility and a coming, the invention of the other promises the possibility of a law and technology, which accord with the 'lesser violence.' It is in this less violent pursuit that the promise of invention, especially as it relates to issues of gender and sexual difference, lies.

90 Shildrik above note 77 at 121

91 Derrida Jacques 'Nietzsche and the Machine' in Derrida Jacques Negotiations: Interventions and Interviews, 1971-2001 Rottenberg Elizabeth (ed and trans) Stanford University Press Stanford 2002 p 215 at 241. 